\title{
Comparative Survey of Entomophagy and Entomotherapeutic Practices in Six Tribes of Eastern Arunachal Pradesh (India)
}

\author{
Jharna Chakravorty ${ }^{1,2}$, Sampat Ghosh ${ }^{1}$ and V Benno Meyer-Rochow ${ }^{2,3^{*}}$
}

\begin{abstract}
A consolidated list of edible insects used in the eastern part of Arunachal Pradesh (N.E. India) by Wangcho (Wancho) and Nocte tribes of the Tirap District and the Shingpo, Tangsa, Deori and Chakma of the Changlang District has been prepared. The list is based on thorough, semi-structured field-interviews with 20 informants of each tribal group. At least 51 insect species, belonging to 9 orders were considered edible. The largest number of the edible species belonged to the Coleoptera (14), followed by 10 each of the Orthoptera and Hymenoptera, 9 of the Hemiptera, 3 Lepidoptera, 2 Isoptera and one each of Ephemeroptera, Odonata and Mantodea. As far as therapeutic uses of insects are concerned, 4 species (Hemiptera) were mentioned by the Wangcho (Wancho). Food insects are chosen by members of the various tribes according to traditional beliefs, taste, regional and seasonal availability of the insects. Depending on the species, only certain, but sometimes all, developmental stages are consumed. Preparation of the food insects for consumption involves mainly roasting or boiling. With the degradation of natural resources, habitat loss, rapid population growth, and increasing 'westernization', the traditional wisdom of North-East Indian tribals related to insect uses is at risk of being lost.
\end{abstract}

Keywords: Edible insects, Wangcho (Wancho), Nocte, Singpho, Tangsa, Deori, Chakma, Traditional wisdom, Biodiversity

\section{Introduction}

Insects are a genuine food item for humans in numerous countries of the world, but as the recent global survey by Mistuhashi [1] has shown, information specifically on India in this regard is patchy and scant. Our review [2] confirmed this and to remedy this sorry state of affairs, we singled out the North-East of India with its multitude of indigenous tribes as the area for our ethno-entomological field work. Our long-term goal is to obtain complete lists of all edible insects for all tribes of the region and to record folk medicinal uses of insects and other arthropods.

Our earlier resesrch has dealt with aspects of entomophagy (i.e., the consumption of insects by humans) amongst tribal members of the Ao-Naga [3,4], Meeteis [4], Khasi [4], Nyishi [5] and Galo [5]. In this paper we

\footnotetext{
* Correspondence: b.meyer-rochow@jacobs-university.de

${ }^{2}$ School of Engineering and Science, Jacobs University, Research II (Rm. 37), D-28759 Bremen, Germany

${ }^{3}$ Department of Biology, Oulu University, Linnanmaa Campus, P.O. Box 3000, FIN-90014 Oulu, Finland

Full list of author information is available at the end of the article
}

expand the study to include observations on tribals of the districts of Tirap and Changlang of Eastern Arunachal Pradesh. The region is remote and difficult to reach and the tribals surveyed (i.e., Nocte, Wangcho (Wancho), Tangsa, Singpho, Deori, and Chakma) have their own languages and traditions.

The ethno-entomological knowledge of the local inhabitants is extensive and handed down orally from generation to generation, but people outside the communities in question are rarely aware of this store of knowledge. Still available, it is, however, more and more in danger of being lost. Problems abound, for much of the region in question is not only hard to reach, but special permits to enter the tribal regions are required from the Indian administration. Moreover, local informants are reluctant to have their voices recorded and rather remain silent when they notice that what they reveal is being taped. There is, thus, always the risk that the information obtained from local informants (tribals of the remote regions often neither speak Hindi nor English so that an interpreter is needed) is to

\section{Biomed Central}


some extent incomplete. Yet, this difficulty needs to be seen as a minor set-back in the context of the massive threats that the traditional uses of insects face in these societies.

These major threats are principally of three kinds. Given that collecting and using insects are still regular components of the local ways of life, an increasing population is likely to require more and more insects. Thus, pressure, especially on the most sought-after species, could reach an extent that is unsustainable. Moreover, the loss of certain species or significant reductions in the number of individuals of ecologically important species due to overuse (for example large numbers of dragon flies collected as nymphs and the subsequent absence of predatory adults) could change the ecological balance in unpredictable ways.

The second threat comes from deforestation and climate change and in both cases could best be described as habitat loss. In the wake of such changes that are likely to affect the stability of the environment, important species of insects (and with them the uses they used to be put to) could disappear. Undoubtedly, there would be other ecological consequences.

The third threat comes from an increase in the introduction and acceptance of western food items and western medicines, both of which eroding and ultimately replacing the traditional uses of insects as food and as components of local therapies administered to treat a variety of health conditions.

For these reasons, we see it as an imperative and urgent task to document as much as we can of the traditional wisdom as long as it is still possible.

\section{Materials and methods}

Extensive field surveys to record the various uses of insects amongst members of the tribes of Eastern Arunachal Pradesh namely Nocte, Wangcho (Wancho), Singpho, Tangsa, Deori and Chakma were carried out during the months of March (2 weeks) and April/May (10 days) in the two districts of Tirap and Changlang in the north-east Indian state of Arunachal Pradesh (Figure 1). Ten villages, selected at random, were visited in each of these two tribal areas. The number of households per village was $20-25$. At least two to three households inhabited by village elders and their families were visited. Recommendations by the headman or village elders to interview certain knowledgeable persons in another village were sometimes followed. The surveys were based on interviews during which a total of 20 persons aged between 45 and 70 years of age (12 male and 8 female) from each tribe were shown museum specimens or photographs of insects.

Kind persistence and expressing a positive attitude towards the consumption of insects by humans were necessary to create an environment of trust. The interviewed people were then asked, often with the help of a local interpreter, simple questions in order to obtain information on the vernacular names of the edible or otherwise important insects, on seasonal availabilities, stages of insects consumed or used, mode of preparation, assumed therapeutic value, folklore related to insects and anything else deemed important in connection with the insect in question. As the knowledge of Hindi or English of the locals was often not great or nonexistent, our questions had to be simple and to the point. Some insects available at the times of the survey were collected by locals from different habitats, e.g., soils and farmland, shrubs and trees, grassland and dwellings. They were then preserved according to standard methods [6] and identified with the help of published keys [7-10]. Where this was not possible, the insects were sent to Kolkata to be identified by entomological experts of the Zoological Survey of India.

According to the website of the district of Tirap (www.tirap.nic.in), maintained by the National Information Center, the region in question lies between latitudes $26^{\circ} 38^{\prime} \mathrm{N}$ to $27^{\circ} 47^{\prime} \mathrm{N}$ and longitudes $96^{\circ} 16^{\prime} \mathrm{E}$ to $95^{\circ} 40^{\prime} \mathrm{E}$. It is bounded by Myanmar towards the south; the Changlang district towards the east; the Dibrugarh district of Assam in the north and Sibsagar (Assam) and Mon districts (Nagaland) towards the west. Tirap covers a total area of 2362 sq.km and has a population of 100,227 (2001 census), of which 52,461 are males and 47,766 females. The population density of 42 inhabitants per sq. $\mathrm{km}$ is the highest in the state of Arunachal Pradesh (approx. 13 per sq. km). The average literacy rate of the inhabitants of Tirap is $42.01 \%$ and in the decade between 1991 and 2001, the population of Tirap grew by 14,759 (corresponding to a $17.21 \%$ increase).

The principle tribes (i.e., 70\% of the total population) that inhabit the district of Tirap are the Wangcho (Wancho), Nocte, and Tutsa. Of these tribal groups, the Wangcho (Wancho) make up about 50\%, Nocte approximately $45 \%$, and Tutsa $5 \%$. Each of the three tribes occupies a distinct geographical area and has its own social norms, customs, beliefs and practices. Although warfare used to be common between them and all are martial Naga tribes, they now live in social harmony with each other, clinging to their own cultures. Their life-style is community based and their livelihood depends on farming and other activities such as contract work in forests, trade in local products, agricultural labour, government employment, etc. The agriculture is primarily of the shifting type (jhum), although people have started to adopt terrace farming as well.

The altitudes vary from around $60 \mathrm{~m}$ above sea level in the north-west to about $1,500 \mathrm{~m}$ in mountainous areas. The climate varies considerably from place to place due to the altitude and nature of the terrain: it is generally cool and highly humid at the elevations and in the valleys. The cold season prevails from the latter part 


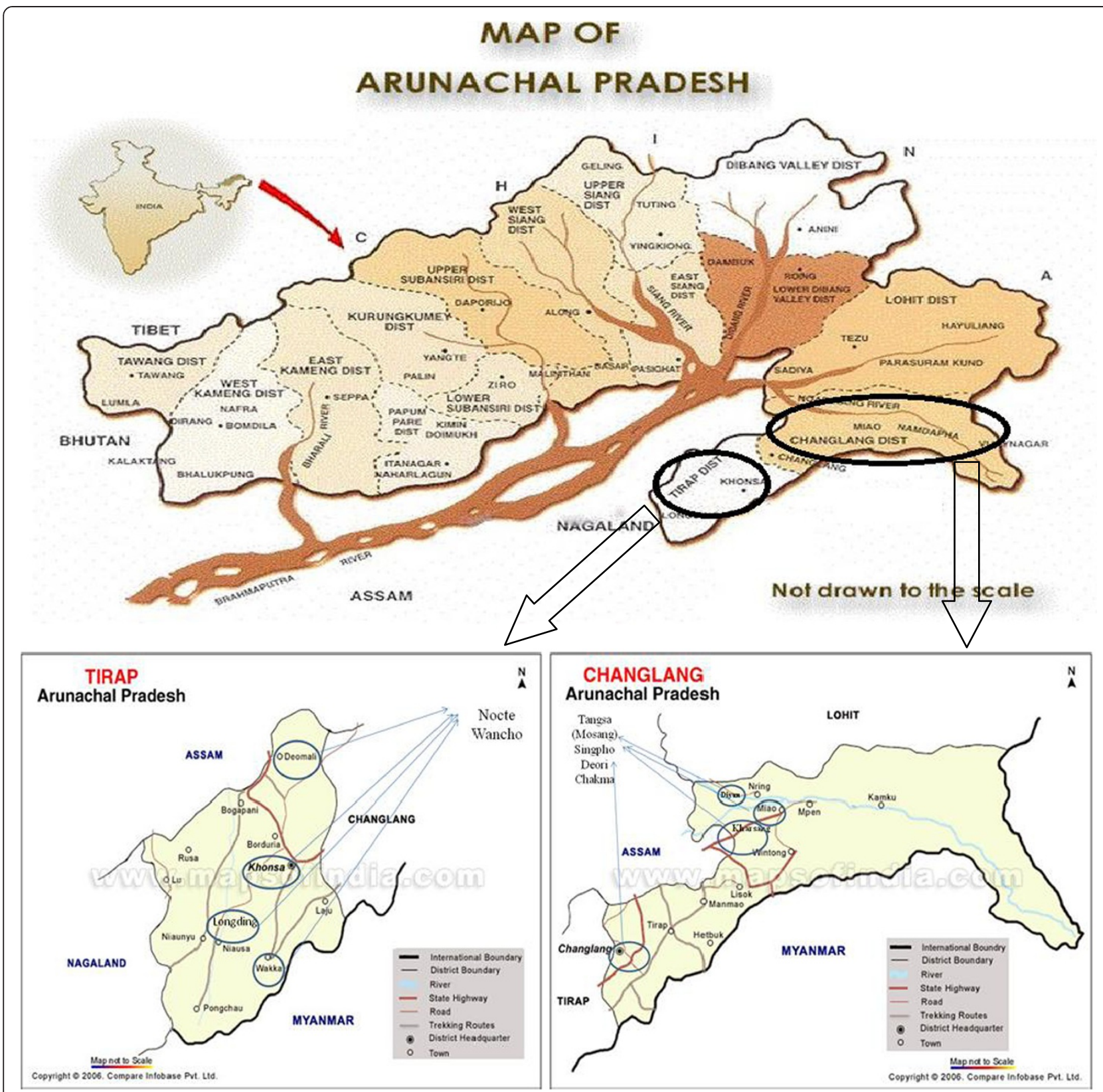

Figure 1 Map of Arunachal Pradesh indicating the study area. Map of Tirap district of Arunachal Pradesh showing study site (Map adopted from www.mapsofindia.com). Map of Changlang district of Arunachal Pradesh showing study site (Map adopted from www.mapsofindia.com).

of November to late February and is followed by premonsoon weather from March to May, while the actual monsoon season lasts from May to about mid October.

According to the website of the Changlang District (www.changlang.nic.in), maintained by the National Information Center, Singpho, Tangsa, Deori and Chakma are the principle inhabitants of the Changlang district, which lies between the latitudes $26^{\circ} 40^{\prime} \mathrm{N}$ and $27^{\circ} 40^{\prime} \mathrm{N}$, and longitudes $95^{\circ} 11^{\prime} \mathrm{E}$ and $97^{\circ} 11^{\prime} \mathrm{E}$. It is bounded by the districts of Tinsukia (Assam) and (Arunachal Pradesh) in the north, by Tirap in the west and by Myanmar in the south-east. Chanlang has an area of $4662 \mathrm{sq} . \mathrm{km}$ and a population of 125,334 (2001 Census), of which as per 2001 census 65,759 are males and 59,575 are females. The literacy rate is 51.98 percent and the decennial growth rate of the population during 1991-2001 was 30.84 for the district. The aboriginal inhabitants of the Changlang district are the Tangsa, Singpho and Tutsa. The Tangsa tribe comprises a number of sub-tribes, namely the Muklom, Havi, Longchang, Mossang, Jugli, Kimsing, Ronrang, Mungrey, Longphi, Longri, Ponthai, Sangwal, Tikhak, Yungkuk, Sakieng and Thamphang. All 
of these occupy the south-eastern hills of the district along the Indo-Myanmar border and the Namchik Basin and differ slightly from each other in dialect and customs.

The Singpho inhabit the area of the plains and foothills of the northern part of the district while the Tutsa live in the western part of the district. Other tribes who have migrated to the district are Nocte, Lisu (Yobin), and Deori. The Chakma came as refugees from Bangladesh. The climatic conditions in this District vary from place to place due to the mountainous nature of the terrain; its average altitude is $580 \mathrm{~m}$.

Places like Miao, Kharsang, Jairampur, Bordumsa and Diyun, which are located at lower elevations and in the valleys, experience hot and humid weather in summer (June-August), but in the hill areas the climate is moderate and pleasant. Between December and February it is cold. January is the coldest month when average maximum and minimum temperatures are about $22^{\circ} \mathrm{C}$ and $13^{\circ} \mathrm{C}$, respectively. August is the hottest month, during which temperatures may occasionally exceed $30^{\circ} \mathrm{C}$. Annual average maximum and minimum temperatures are $26.96^{\circ} \mathrm{C}$ and $18.63^{\circ} \mathrm{C}$. Like temperature, rainfall is also much influenced by the terrain, ranging from $3800 \mathrm{~mm}$ to $4866 \mathrm{~mm}$ per annum. Major rainfall is received during June through October.

\section{Results and discussion}

The present study revealed that a total of 51 insect species (including both identified and unidentified species), principally belonging to 21 families and 9 orders, find acceptance as food by the local ethnic people. Species distribution is such that Ephemeroptera, Odonata and Mantodea were represented by one species each; 10 species each belonged to the orders Orthoptera and Hymenoptera, 9 were representatives of the Hemiptera (including Homoptera), 14 of the Coleoptera, 3 of the Lepidoptera, and 2 of the Isoptera. Figure 2 shows the order-wise distribution of the identified edible insects of the tribes studied. However, the list of edible insects is likely to be incomplete and probably much longer, because we cannot rule out the possibility of additional species accepted as food, but not present or not shown to the local people at the time of our interviews. Some information might also have deliberately been withheld for reasons of taboos associated with certain species or a feeling of shame to admit their consumption [11].

An inventory of the identified edible insects of the six ethnic tribes of the studied area is presented in Tables 1 , $2,3,4,5,6$. The Wangcho (Wancho) were found to consume at least 20 insect species, including some with therapeutic uses. Of these 20 species, 4 were Orthoptera, 6 were Hymenoptera, 7 were Hemiptera, and 3 were Coleoptera (Table 1). Out of the 7 Hemiptera, 4 were reported by Wangcho (Wancho) informants to be exclusively used for therapeutic purposes. Except for the Wangcho (Wancho), no members of the other tribes mentioned any therapeutic uses of insects, but this does not mean that they had absolutely no medicinal uses for them. More likely only a few traditional healers would know (or be allowed) to disclose such uses. The use of honey as a remedy for a variety of ills, however, was widely known to the members of all tribes.

The Nocte consume at least 16 species of insects, which include 4 Orthoptera, 5 Hymenoptera, 3 Hemiptera, 2 Isoptera and 1 species each belonging to the Odonata and Ephemeroptera (Table 2). Singpho people consume at least 14 species, which include 3 species each of the Orthoptera and Hemiptera; 4 species belong to the Hymenoptera and 2 each to the Isoptera and Coleoptera (Table 3).

Members of the Tangsa (Mosang or Lumphi subtribes) comsume at least 9 species, of which 6 are Hymenoptera and 3 Hemiptera (Table. 4). Insects belonging to at least 12 species found acceptance as food by the Deori people. Six of the edible species were Orthoptera and 3 each were Lepidoptera and Hymenoptera (Table 5). The Chakma consume at least 15 species, which comprise 4

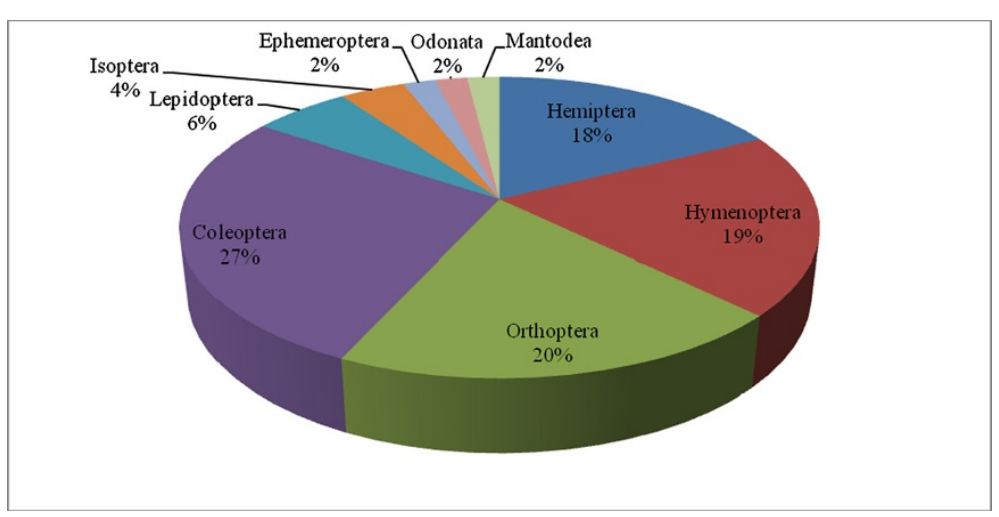

Figure 2 Orderwise distribution of edible insects used by Eastern Arunachal tribes. 
Table 1 Inventory of edible insects used by members of the Wangcho (Wancho) tribe of Eastern Arunachal Pradesh

\begin{tabular}{|c|c|c|c|c|c|c|c|}
\hline $\begin{array}{l}\text { Scientific } \\
\text { name }\end{array}$ & Order & Family & $\begin{array}{l}\text { English } \\
\text { name }\end{array}$ & $\begin{array}{l}\text { Vernacular } \\
\text { name }\end{array}$ & $\begin{array}{c}\text { Seasonal } \\
\text { availability }\end{array}$ & Mode of intake & Remarks \\
\hline $\begin{array}{c}\text { Chondacris } \\
\text { rosea (DeGeer } \\
1773)\end{array}$ & Orthoptera & Acrididae & $\begin{array}{l}\text { Short horn } \\
\text { grasshopper }\end{array}$ & Okuk & Sept- Nov & $\begin{array}{l}\text { Head, appendages and wings } \\
\text { are discarded and bodies are } \\
\text { roasted }\end{array}$ & \\
\hline Unidentified & Orthoptera & Acrididae & $\begin{array}{l}\text { Short horn } \\
\text { grasshopper }\end{array}$ & Okuk & Sept- Oct & roasted & \\
\hline $\begin{array}{l}\text { Brachytrupes } \\
\text { sp. }\end{array}$ & Orthoptera & Gryllidae & Cricket & Okuk & May- Sept & $\begin{array}{c}\text { Head, appendages and wings } \\
\text { are discarded, bodies are } \\
\text { roasted }\end{array}$ & \\
\hline $\begin{array}{c}\text { Brachytrupes } \\
\text { orientalis } \\
\text { (Burmeister } \\
\text { 1838) } \\
\end{array}$ & Orthoptera & Gryllidae & Cricket & Okuk & May- Sept & $\begin{array}{c}\text { Head, appendages and wings } \\
\text { are discarded, bodies are } \\
\text { roasted }\end{array}$ & \\
\hline $\begin{array}{c}\text { Aspongopus } \\
\text { nepalensis } \\
\text { Westwood } \\
1837\end{array}$ & Hemiptera & Pentatomidae & Bug & Longvia & Dec- Feb & $\begin{array}{c}\text { Raw paste with chili and } \\
\text { ginger }\end{array}$ & $\begin{array}{l}\text { Sometimes consumption } \\
\text { causes psychiatric disorder }\end{array}$ \\
\hline $\begin{array}{l}\text { Halyomorpha } \\
\text { picus } \\
\text { (Fabricius } \\
\text { 1794) } \\
\end{array}$ & Hemiptera & Pentatomidae & Bug & $\begin{array}{l}\text { Nyajong } \\
\text { waekhoi }\end{array}$ & Nov- Feb & $\begin{array}{l}\text { Suck the sting in cold and } \\
\text { cough }\end{array}$ & $\begin{array}{l}\text { Not reported as a normal } \\
\text { food item for Wangcho } \\
\text { (Wancho) people, but used } \\
\text { for therapeutic purposes }\end{array}$ \\
\hline $\begin{array}{l}\text { Nezara } \\
\text { viridula } \\
\text { (Linnaeus } \\
\text { 1758) }\end{array}$ & Hemiptera & Pentatomidae & Bug & Jakwikhoi & Dec- Feb & Wings are discarded, roasted & - \\
\hline $\begin{array}{l}\text { Rhynchoris } \\
\text { humeralis } \\
\text { (Thunberg } \\
1783 \text { ) }\end{array}$ & Hemiptera & Pentatomidae & Bug & Viapath & Jan- Mar & $\begin{array}{l}\text { People use to press the } \\
\text { lower portion of the insect to } \\
\text { remove the stink gland, } \\
\text { wings are discarded and } \\
\text { insect is roasted }\end{array}$ & $\begin{array}{l}\text { The secretion is poisonous } \\
\text { for the eye, yellowish in } \\
\text { colour and it takes one } \\
\text { week to remove it from } \\
\text { the hand }\end{array}$ \\
\hline $\begin{array}{c}\text { Dalader } \\
\text { acuticosta } \\
\text { (Amyot \& } \\
\text { Serville 1843) } \\
\end{array}$ & Hemiptera & Pyrrhocoridae & Bug & Waekhoi & Dec- Feb & $\begin{array}{l}\text { Suck the sting in cold and } \\
\text { cough }\end{array}$ & $\begin{array}{l}\text { Not reported as a normal } \\
\text { food item for Wangcho } \\
\text { (Wancho) people, but used } \\
\text { for therapeutic purposes }\end{array}$ \\
\hline $\begin{array}{l}\text { Mictis } \\
\text { tenebrosa } \\
\text { (Fabricius } \\
1787 \text { ) }\end{array}$ & Hemiptera & Pyrrhocoridae & Bug & Waekhoi & April- Aug & $\begin{array}{l}\text { Suck the sting in cold and } \\
\text { cough }\end{array}$ & $\begin{array}{l}\text { Not reported as a normal } \\
\text { food item for Wangcho } \\
\text { (Wancho) people, but used } \\
\text { for therapeutic purposes }\end{array}$ \\
\hline $\begin{array}{c}\text { Antilochus } \\
\text { coqueberti } \\
\text { (Fabricius } \\
1803 \text { ) }\end{array}$ & Hemiptera & Pyrrhocoridae & Bug & $\begin{array}{l}\text { Wanwikhoi/ } \\
\text { Wanchong }\end{array}$ & $\begin{array}{l}\text { Around the } \\
\text { year }\end{array}$ & Raw or roasted & $\begin{array}{l}\text { Species is used only for } \\
\text { therapeutic purposes }\end{array}$ \\
\hline Dorcus sp. & Coleoptera & Lucanidae & Stag beetle & Mogap magai & Aug- Oct & $\begin{array}{c}\text { Appendages discarded, } \\
\text { roasted }\end{array}$ & \\
\hline Unidentified & Coleoptera & Lucanidae & Stag beetle & Mogap magai & Jul- Sept & $\begin{array}{c}\text { Appendages discarded, } \\
\text { roasted }\end{array}$ & \\
\hline $\begin{array}{l}\text { Unidentified } \\
\text { small species }\end{array}$ & Coleoptera & & & $\begin{array}{l}\text { Mophong } \\
\text { molong/ } \\
\text { Notphong }\end{array}$ & June - Sept & Boiled or roasted & \\
\hline $\begin{array}{l}\text { Apis mellifera } \\
\text { Linnaeus } 1758 \\
\end{array}$ & Hymenoptera & Apidae & Honeybee & Nakat & Nov- Jan & $\begin{array}{c}\text { Honey and sometimes larvae, } \\
\text { pupae and queen boiled }\end{array}$ & \\
\hline Apis sp. & Hymenoptera & Apidae & Honeybee & Nakat & Nov -Jan & $\begin{array}{c}\text { Honey and sometimes larvae, } \\
\text { pupae and queen boiled }\end{array}$ & \\
\hline Xylocopa sp & Hymenoptera & Xylocopidae & Bee & Nakat & Nov-Mar & & \\
\hline Unidentified & Hymenoptera & Vespidae & Wasp & Nahtam & Nov- Jan & $\begin{array}{l}\text { Immature stages raw or roasted } \\
\text { nymph and queen boiled }\end{array}$ & \\
\hline Unidentified & Hymenoptera & Vespidae & Wasp & Thokananu & Oct- Dec & Larvae & \\
\hline $\begin{array}{l}\text { Oecophylla } \\
\text { smaragdina } \\
\text { Fabricius } 1775\end{array}$ & Hymenoptera & Formicidae & Red ant & Thajao & $\begin{array}{l}\text { Round the } \\
\text { year }\end{array}$ & Pupae are consumed & \\
\hline
\end{tabular}


Table 2 Inventory of edible insects used by members of the Nocte tribe of Eastern Arunachal Pradesh

\begin{tabular}{|c|c|c|c|c|c|c|c|}
\hline Scientific name & Order & Family & $\begin{array}{l}\text { English } \\
\text { name }\end{array}$ & $\begin{array}{l}\text { Vernacular } \\
\text { name }\end{array}$ & $\begin{array}{c}\text { Seasonal } \\
\text { availability }\end{array}$ & Mode of intake & Remarks \\
\hline Unidentified & Ephemeroptera & & Mayfly & Along/ Phin & Sept- Nov & Roasted & \\
\hline Termes sp. & Isoptera & Termitidae & Termite & Akhun & May- June & $\begin{array}{l}\text { Roasted with local edible } \\
\text { leaves, wings discarded }\end{array}$ & \\
\hline Odontotermes sp. & Isoptera & Odontotermitidae & & Akhun & May- June & $\begin{array}{l}\text { Roasted with local edible } \\
\text { leaves, wings discarded }\end{array}$ & \\
\hline Unidentified & Odonata & Gomphidae & $\begin{array}{l}\text { Odonate } \\
\text { larvae of } \\
\text { dragonfly }\end{array}$ & Moogi & Sept - Oct & $\begin{array}{c}\text { Roasted with local edible } \\
\text { leaves }\end{array}$ & \\
\hline Brachytrupes sp. & Orthoptera & Gryllidae & Cricket & $\begin{array}{l}\text { Loothong/ } \\
\text { Idmon/ Churu }\end{array}$ & May- Sept & $\begin{array}{l}\text { Antennae, wings and anal } \\
\text { cerci discarded, bind with } \\
\text { local leaves and roasted }\end{array}$ & \\
\hline $\begin{array}{l}\text { Brachytrupes } \\
\text { orientalis } \\
\text { (Burmeister } \\
\text { 1838) }\end{array}$ & Orthoptera & Gryllidae & Cricket & $\begin{array}{l}\text { Loothong/ } \\
\text { Idmon/ Churu }\end{array}$ & May- Sept & $\begin{array}{l}\text { Antennae, wings and anal } \\
\text { cerci discarded, bind with } \\
\text { local leaves and roasted }\end{array}$ & \\
\hline Macrolyristes sp. & Orthoptera & Tettigoniidae & Katydid & $\begin{array}{l}\text { Kokchug/ } \\
\text { Headboon }\end{array}$ & Sept- Oct & $\begin{array}{c}\text { Antennae, wings and anal } \\
\text { cerci discarded, bind with } \\
\text { local edible leaves and } \\
\text { roasted }\end{array}$ & \\
\hline Unidentified & Orthoptera & Tettigoniidae & Katydid & Kotkot & Aug- Nov & Roasted & \\
\hline $\begin{array}{c}\text { Aspongopus } \\
\text { nepalensis } \\
\text { Westwood } 1837\end{array}$ & Hemiptera & Pentatomidae & Bug & $\begin{array}{l}\text { Longheto/ } \\
\text { Seve }\end{array}$ & Dec- Feb & $\begin{array}{c}\text { Boiled or prepared as } \\
\text { chutney }\end{array}$ & $\begin{array}{c}\text { Sometimes } \\
\text { consumption causes } \\
\text { psychiatric disorder }\end{array}$ \\
\hline $\begin{array}{c}\text { Tessaratoma } \\
\text { quadrata Distant } \\
1902\end{array}$ & Hemiptera & Pentatomidae & Bug & $\begin{array}{l}\text { Siviliangkhan/ } \\
\text { Heta }\end{array}$ & Jan- Mar & $\begin{array}{c}\text { Wings and appendages } \\
\text { discarded, bodies are roasted } \\
\text { ("gi") }\end{array}$ & $\begin{array}{c}\text { Nocte people } \\
\text { reported secretion } \\
\text { from backside is } \\
\text { quite dangerous for } \\
\text { eye }\end{array}$ \\
\hline $\begin{array}{c}\text { Halyomorpha } \\
\text { picus (Fabricius } \\
\text { 1794) }\end{array}$ & Hemiptera & Pentatomidae & Bug & $\begin{array}{l}\text { Longliasivi/ } \\
\text { Longlia }\end{array}$ & Nov- Feb & $\begin{array}{c}\text { Wings and appendages } \\
\text { discarded, bodies are roasted } \\
\text { ("gi") }\end{array}$ & \\
\hline $\begin{array}{c}\text { Apis (cerana) } \\
\text { indica (Fabricius } \\
1798)\end{array}$ & Hymenoptera & Apidae & Honeybee & Nyakui & Nov- Jan & $\begin{array}{l}\text { Immature stages are } \\
\text { consumed, boiled or roasted }\end{array}$ & $\begin{array}{c}\text { Honey is used } \\
\text { widely as medicinal } \\
\text { agent }\end{array}$ \\
\hline $\begin{array}{l}\text { Apis mellifera } \\
\text { Linnaeus } 1758\end{array}$ & Hymenoptera & Apidae & Honeybee & Nyakui & Nov- Jan & $\begin{array}{l}\text { Immature stages are } \\
\text { consumed, boiled or roasted }\end{array}$ & $\begin{array}{c}\text { Honey is used } \\
\text { widely as medicinal } \\
\text { agent }\end{array}$ \\
\hline Unidentified & Hymenoptera & $\begin{array}{l}\text { Apidae or } \\
\text { Vespidae }\end{array}$ & $\begin{array}{l}\text { Bee or } \\
\text { wasp }\end{array}$ & Nyakui & Nov - Jan & $\begin{array}{l}\text { Immature stages are } \\
\text { consumed, boiled or roasted }\end{array}$ & \\
\hline Xylocopa sp & Hymenoptera & Xylocopidae & Bee & Nyakui & Nov-Mar & $\begin{array}{l}\text { Immature stages are } \\
\text { consumed, boiled or roasted }\end{array}$ & \\
\hline $\begin{array}{l}\text { Oecophylla } \\
\text { smaragdina } \\
\text { Fabricius } 1775\end{array}$ & Hymenoptera & Formicidae & Red ant & $\begin{array}{l}\text { Aukhithio/ } \\
\text { Thapi/Khawa }\end{array}$ & $\begin{array}{l}\text { Round the } \\
\text { year }\end{array}$ & $\begin{array}{l}\text { People use to take the hive } \\
\text { and treat it with hot water, } \\
\text { keep it as it is in pan and } \\
\text { roasted it with masala }\end{array}$ & \\
\hline
\end{tabular}

Orthoptera, 10 Coleoptera and 1 Mantodea (Table 6). Figure 3 represents the comparative graphical representation of entomophagy of the studied ethnic groups.

\section{Seasonal availability}

Although insects generally occur throughout the year, their presence and abundance is determined by the presence and availability of their food plants as well as seasonal and local weather conditions. Reports on the seasonal abundance of the edible insects indicated that the maximum number of edible coleopteran species occurred between June and September (pre monsoon and monsoon); in winter and early spring, numbers of these insects dropped considerably. Acridid species occurred mostly during September and October, but gryllids were most abundant in the 4 months before, namely May through August.

Most of the bees and wasps (Hymenoptera) were consumed during the months November to February (winter season), but the weaver ant Oecophylla smaragdina was 
Table 3 Inventory of edible insects used by members of the Singpho tribe of Eastern Arunachal Pradesh

\begin{tabular}{|c|c|c|c|c|c|c|c|}
\hline Scientific name & Order & Family & $\begin{array}{c}\text { English } \\
\text { name }\end{array}$ & $\begin{array}{c}\text { Vernacular } \\
\text { name }\end{array}$ & $\begin{array}{c}\text { Seasonal } \\
\text { availability }\end{array}$ & Mode of intake & Remarks \\
\hline Termes sp. & Isoptera & Termitidae & Termite & khukan & May- June & Wing are discarded, fried & \\
\hline Odontotermes sp. & Isoptera & Odontotermitidae & & khukan & May - June & Wings are discarded, fried & \\
\hline $\begin{array}{c}\text { Chondacris rosea } \\
\text { (DeGeer 1773) }\end{array}$ & Orthoptera & Acrididae & $\begin{array}{c}\text { Short } \\
\text { horned } \\
\text { grasshopper }\end{array}$ & Macherie & Sept- Nov & $\begin{array}{l}\text { Head, appendages and } \\
\text { wings are bodies are } \\
\text { discarded and roast }\end{array}$ & \\
\hline Brachytrupes sp. & Orthoptera & Gryllidae & Cricket & Gdun & May- Sept & $\begin{array}{c}\text { Head, antennae and legs } \\
\text { are discarded and bodies } \\
\text { are roasted }\end{array}$ & \\
\hline $\begin{array}{c}\text { Brachytrupes } \\
\text { orientalis } \\
\text { (Burmeister } \\
\text { 1838) } \\
\end{array}$ & Orthoptera & Gryllidae & Cricket & Gdun & May- Sept & $\begin{array}{c}\text { Head, antennae and legs } \\
\text { are discarded and bodies } \\
\text { are roasted }\end{array}$ & \\
\hline $\begin{array}{c}\text { Aspongopus } \\
\text { nepalensis } \\
\text { Westwood } 1837\end{array}$ & Hemiptera & Pentatomidae & Bug & Chammah & Dec- Feb & $\begin{array}{l}\text { Fried or roasted used after } \\
\text { removal of stink gland } \\
\text { that tastes bitter }\end{array}$ & $\begin{array}{c}\text { Sometimes consumption } \\
\text { causes psychiatric } \\
\text { disorder }\end{array}$ \\
\hline $\begin{array}{l}\text { Mictis tenebrosa } \\
\text { (Fabricius 1787) }\end{array}$ & Hemiptera & Pyrrhocoridae & Bug & Chammah & April- Aug & Boiled with vegetables & $\begin{array}{c}\text { Singpho people reported } \\
\text { that these insects are } \\
\text { collected from rotten } \\
\text { bamboo }\end{array}$ \\
\hline Unidentified & Hemiptera & Cicadidae & Cicada & Machera & April- Aug & Roasted & \\
\hline $\begin{array}{c}\text { Xylotrupes gideon } \\
\text { Guérin-Méneville } \\
1830\end{array}$ & Coleoptera & Scarabaeidae & Beetle & Chingiet & May- July & $\begin{array}{l}\text { Legs discarded, roasted or } \\
\text { fried }\end{array}$ & \\
\hline $\begin{array}{c}\text { Batocera roylei } \\
\text { Hope } 1833\end{array}$ & Coleoptera & Cerambycidae & $\begin{array}{l}\text { Long horn } \\
\text { beetle }\end{array}$ & Chingiet & June- Aug & $\begin{array}{l}\text { Antennae and wings } \\
\text { discarded, roasted }\end{array}$ & \\
\hline $\begin{array}{c}\text { Apis (cerana) } \\
\text { indica (Fabricius } \\
1798)\end{array}$ & Hymenoptera & Apidae & Honeybee & Lagat & Nov- Jan & $\begin{array}{l}\text { Immature stages and } \\
\text { honey is being consumed }\end{array}$ & $\begin{array}{l}\text { Honey is used widely as } \\
\text { medicinal agent }\end{array}$ \\
\hline $\begin{array}{l}\text { Apis mellifera } \\
\text { Linnaeus } 1758\end{array}$ & Hymenoptera & Apidae & Honeybee & Lagat & Nov- Jan & $\begin{array}{c}\text { Immature stages and } \\
\text { honey are being } \\
\text { consumed }\end{array}$ & $\begin{array}{c}\text { Honey is used widely as } \\
\text { medicinal agent }\end{array}$ \\
\hline Eumenes sp. & Hymenoptera & Vespidae & Wasp & Katpatkai & Nov-Dec & $\begin{array}{c}\text { Generally larval stages are } \\
\text { being consumed, when } \\
\text { wings are not developed, } \\
\text { fried }\end{array}$ & \\
\hline $\begin{array}{c}\text { Oecophylla } \\
\text { smaragdina } \\
\text { Fabricius } 1775\end{array}$ & Hymenoptera & Formicidae & Red ant & Makhao & $\begin{array}{l}\text { Round the } \\
\text { year }\end{array}$ & Pupae boiled or fried & \\
\hline
\end{tabular}

available throughout the year. Insects belonging to the order Hemiptera were reported to be restricted to the period of December to February, although at least one cicada and one pyrrhocorid bug (i.e., Mictis tenebrosa) were found to be available only between April to August (i.e., the pre-monsoon season). The hemipteran bug Antilochus sp. occurs year round according to the respondents.

Using insects to coincide with a particular season or period is one example of the richness of the traditional knowledge available in the local populations. Neupane et al. [12] investigated the rearing biology of Samia ricini in Nepal, where local people did not recommend rearing it during the cold months (November to April), because of the longer life cycle of 114-126 days during that time; they recommended instead the months of
March to November, when life cycles were much shorter, amounting to just 38-61 days. Our study revealed that the Deori's practice to rear this species during the months of April to September (mainly for the consumption of the larvae) had been passed down from generation to generation and agrees with the observation from Nepal. Sequestration of edible insects on a seasonal basis will undoubtedly have been an experience of the ethnic people of the area since ancient times and will have played an important role in the seasonally varied consumption of different insect species. However, a deeper study of this phenomenon had not been the objective of this initial survey. A detailed investigation of this aspect of entomophagy, although clearly worthwhile, would need to be carried out over at least a 12 month 
Table 4 Inventory of edible insects used by members of the Tangsa tribe of Eastern Arunachal Pradesh

\begin{tabular}{|c|c|c|c|c|c|c|c|}
\hline Scientific name & Order & Family & $\begin{array}{l}\text { English } \\
\text { name }\end{array}$ & $\begin{array}{l}\text { Vernacular } \\
\text { name }\end{array}$ & $\begin{array}{c}\text { Seasonal } \\
\text { availability }\end{array}$ & Mode of intake & Remarks \\
\hline $\begin{array}{c}\text { Aspongopus } \\
\text { nepalensis } \\
\text { Westwood } 1837\end{array}$ & Hemiptera & Pentatomidae & Bug & Shiphon & Dec- Feb & $\begin{array}{l}\text { Fried or roasted after removal of } \\
\text { stink gland that tastes bitter }\end{array}$ & $\begin{array}{l}\text { Sometimes } \\
\text { consumption causes } \\
\text { psychiatric disorder }\end{array}$ \\
\hline $\begin{array}{l}\text { Tessaratoma } \\
\text { quadrata } \\
\text { Distant } 1902\end{array}$ & Hemiptera & Pentatomidae & Bug & $\begin{array}{l}\text { Shipho/ } \\
\text { Nagoo }\end{array}$ & Jan- Mar & Roasted & \\
\hline Unidentified & Hemiptera & Cicadidae & Cicada & Kapchera & April- Aug & Roasted & $\begin{array}{c}\text { Generally consumed } \\
\text { by children }\end{array}$ \\
\hline $\begin{array}{c}\text { Apis (cerana) } \\
\text { indica (Fabricius } \\
\text { 1798) }\end{array}$ & Hymenoptera & Apidae & Honeybee & $\begin{array}{l}\text { Yankung/ } \\
\text { yakay }\end{array}$ & Nov- Jan & $\begin{array}{c}\text { Immature stages and honey is being } \\
\text { consumed; larvae are also being } \\
\text { consumed, boiled }\end{array}$ & \\
\hline $\begin{array}{l}\text { Apis mellifera } \\
\text { Linnaeus } 1758\end{array}$ & Hymenoptera & Apidae & Honeybee & Yakay & Nov- Jan & $\begin{array}{l}\text { Immature sages and honey are } \\
\text { being consumed }\end{array}$ & $\begin{array}{l}\text { Honey is used widely } \\
\text { as medicinal agent }\end{array}$ \\
\hline Unidentified & Hymenoptera & Vespidae & Wasp & Yanjung & Oct- Dec & Immature are being consumed & \\
\hline Eumenes sp. & Hymenoptera & Vespidae & Wasp & Longli & Nov- Dec & $\begin{array}{c}\text { Generally larval stage is being } \\
\text { consumed, when wings are not } \\
\text { developed, fried }\end{array}$ & \\
\hline $\begin{array}{l}\text { Vespa orientalis } \\
\text { Linnaeus } 1771\end{array}$ & Hymenoptera & Vespidae & Hornet & Yandok & Nov-Feb & Immature stages are boiled & \\
\hline $\begin{array}{l}\text { Oecophylla } \\
\text { smaragdina } \\
\text { Fabricius } 1775\end{array}$ & Hymenoptera & Formicidae & Red ant & Saisho & $\begin{array}{l}\text { Round the } \\
\text { year }\end{array}$ & Larvae and pupae boiled or fried & \\
\hline
\end{tabular}

Table 5 Inventory of edible insects used by members of the Deori tribe of Eastern Arunachal Pradesh

\begin{tabular}{|c|c|c|c|c|c|c|c|}
\hline Scientific name & Order & Family & English name & $\begin{array}{l}\text { Vernacular } \\
\text { name }\end{array}$ & $\begin{array}{c}\text { Seasonal } \\
\text { availability }\end{array}$ & Mode of intake & Remarks \\
\hline $\begin{array}{l}\text { Chondacris rosea } \\
\text { (DeGeer 1773) }\end{array}$ & Orthoptera & Acrididae & $\begin{array}{l}\text { Short horn } \\
\text { grasshopper }\end{array}$ & Phoring & Sept- Nov & $\begin{array}{l}\text { Legs and wings are discarded, roasted } \\
\text { or fried with mustard oil }\end{array}$ & \\
\hline Laptysma sp. & Orthoptera & Acrididae & $\begin{array}{l}\text { Short horn } \\
\text { grasshopper }\end{array}$ & Phoring & Aug- Oct & $\begin{array}{l}\text { Legs and wings discarded, roasted or } \\
\text { fried with mustard oil }\end{array}$ & \\
\hline Unidentified & Orthoptera & Acrididae & $\begin{array}{l}\text { Short horn } \\
\text { grasshopper }\end{array}$ & Phoring & Sept- Oct & $\begin{array}{l}\text { Legs and wings are discarded, roasted } \\
\text { or fried with mustard oil }\end{array}$ & \\
\hline Brachytrupes sp. & Orthoptera & Gryllidae & Cricket & Shingapok & May- Sept & $\begin{array}{l}\text { Wings, legs and antennae discarded } \\
\text { and bodies are fried with mustard oil }\end{array}$ & \\
\hline $\begin{array}{c}\text { Brachytrupes } \\
\text { orientalis (Burmeister } \\
\text { 1838) }\end{array}$ & Orthoptera & Gryllidae & Cricket & Shingapok & May- Sept & $\begin{array}{l}\text { Wings, legs and antennae discarded } \\
\text { and bodies are fried with oil }\end{array}$ & \\
\hline Unidentified & Orthoptera & Tettigoniidae & Katydid & Phoring & Sept- Oct & $\begin{array}{l}\text { Legs, antennae and wings are } \\
\text { discarded, roasted or fried with oil }\end{array}$ & \\
\hline $\begin{array}{l}\text { Apis mellifera } \\
\text { Linnaeus } 1758\end{array}$ & Hymenoptera & Apidae & Honeybee & Moumakhi & Nov- Jan & Honey & \\
\hline Apis sp. & Hymenoptera & Apidae & Honeybee & Moumakhi & Nov- Jan & Honey & \\
\hline $\begin{array}{c}\text { Oecophylla } \\
\text { smaragdina Fabricius } \\
1775\end{array}$ & Hymenoptera & Formicidae & Red ant & Semete & $\begin{array}{l}\text { All year } \\
\text { round }\end{array}$ & Pupae & \\
\hline $\begin{array}{c}\text { Samia ricini } \\
\text { (Donovan 1798) }\end{array}$ & Lepidoptera & Saturniidae & $\begin{array}{l}\text { Saturniid silk } \\
\text { moth }\end{array}$ & Palu & April- Sept & $\begin{array}{l}\text { Large caterpillar stages, pupae boiled } \\
\text { and fried }\end{array}$ & \\
\hline $\begin{array}{c}\text { Antheraea } \\
\text { assamensis Helfer } \\
1837\end{array}$ & Lepidoptera & Saturniidae & Muga silk moth & Palu & May- Sept & $\begin{array}{l}\text { Large caterpillar stages, pupae boiled } \\
\text { and fried }\end{array}$ & \\
\hline $\begin{array}{l}\text { Bombyx mori } \\
\text { (Linnaeus 1758) }\end{array}$ & Lepidoptera & Bombycidae & $\begin{array}{l}\text { Silkworm or } \\
\text { mulberry silk } \\
\text { worm }\end{array}$ & Palu & May- Sept & $\begin{array}{l}\text { Large caterpillar stages, pupae boiled } \\
\text { and fried }\end{array}$ & \\
\hline
\end{tabular}


Table 6 Inventory of edible insects used by members of the Chakma tribe of Eastern Arunachal Pradesh

\begin{tabular}{|c|c|c|c|c|c|c|c|}
\hline Scientific name & Order & Family & English name & $\begin{array}{l}\text { Vernacular } \\
\text { name }\end{array}$ & $\begin{array}{c}\text { Seasonal } \\
\text { availability }\end{array}$ & Mode of intake & Remarks \\
\hline $\begin{array}{c}\text { Chondacris rosea (DeGeer } \\
1773 \text { ) }\end{array}$ & Orthoptera & Acrididae & $\begin{array}{l}\text { Short horn } \\
\text { grasshopper }\end{array}$ & Phiring & Sept- Nov & $\begin{array}{c}\text { Roasted or fried with mustard } \\
\text { oil }\end{array}$ & \\
\hline Brachytrupes sp. & Orthoptera & Gryllidae & Cricket & Gumro & May- Sept & $\begin{array}{l}\text { Wings discarded and fried } \\
\text { with mustard oil }\end{array}$ & \\
\hline $\begin{array}{l}\text { Brachytrupes orientalis } \\
\text { (Burmeister 1838) }\end{array}$ & Orthoptera & Gryllidae & Cricket & Gumro & May- Sept & $\begin{array}{c}\text { Wings discarded and fried } \\
\text { with oil }\end{array}$ & \\
\hline Microcentum sp. (?) & Orthoptera & Tettigoniidae & Katydid & $\begin{array}{l}\text { Elbetto } \\
\text { phiring }\end{array}$ & Aug- Oct & Roasted or fried with oil & \\
\hline Mantis sp. & Mantodea & & Preying mantis & Aasphiring & Aug-Oct & Fried with oil & \\
\hline Aristobia sp. & Coleoptera & Cerambycidae & $\begin{array}{l}\text { Long horn } \\
\text { beetle }\end{array}$ & Chorgipok & June- Aug & Roasted or fried with oil & \\
\hline Batocera roylei Hope 1833 & Coleoptera & Cerambycidae & $\begin{array}{l}\text { Long horn } \\
\text { beetle }\end{array}$ & Chorgipok & June- Aug & Roasted or fried & \\
\hline Haplocerambyx sp. & Coleoptera & Cerambycidae & $\begin{array}{l}\text { Long horn } \\
\text { beetle }\end{array}$ & Chorgipok & June- Sept & Roasted or fried with oil & \\
\hline Sternocera sp. & Coleoptera & Buprestidae & Beetle & Keshkumari & June- Sept & Roasted or fried with oil & \\
\hline Helicupris sp. & Coleoptera & Scarabaeidae & Beetle & Shimpok & June- Sept & Roasted or fried with oil & \\
\hline Unidentified sp. & Coleoptera & Scarabaeidae & Beetle & Shimphoo & June- Sept & Roasted or fried with oil & \\
\hline Anomala sp. & Coleoptera & Scarabaeidae & Beetle & Elphobang & Aug-Sept & Roasted or fried with oil & \\
\hline Propomacrus sp. & Coleoptera & Scarabaeidae & Beetle & Phobang & June- Sept & Roasted or fried with oil & \\
\hline Lepidiota sp. & Coleoptera & Scarabaeidae & Beetle & Phobang & Aug-Sept & Roasted or fried with oil & \\
\hline $\begin{array}{l}\text { Lucanus laminifer } \\
\text { Waterhouse } 1890 .\end{array}$ & Coleoptera & Lucanidae & Stag beetle & Komrengpok & June- Sept & Roasted or fried with oil & \\
\hline
\end{tabular}

period by a researcher resident in the area or areas under debate.

\section{Stages and modes of insect consumption}

Generally speaking, edible insects were consumed at all stages of development, i.e. egg, larva, pupa (when present), and adult. With Orthoptera and Hemiptera, adult stages were more highly valued than nymphs. Hymenoptera were eaten at all developmental stages, although eggs and honey were mentioned to be used particularly widely. It needs to be pointed out here that when the locals speak of insect eggs' they usually mean the pupal stage. For species belonging to the Vespidae, the larvae, i.e. the whitish grubs, were preferred. Pupae of the ant Oecophylla smaragdina

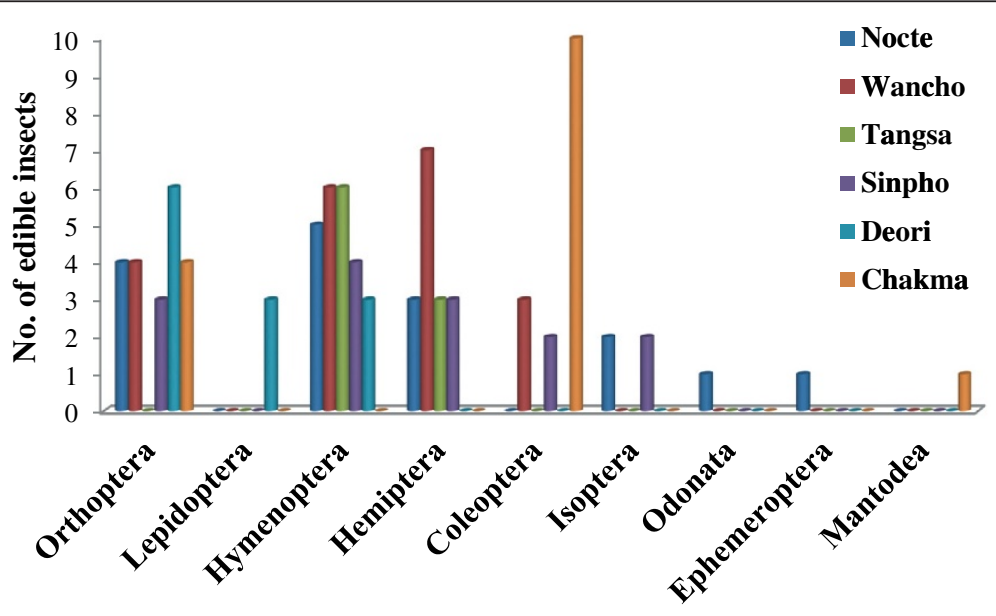

Insect order

Figure 3 Comparative graphical representation of entomophagy of studied ethnic. 
were commonly consumed although some members of the Nocte tribe mentioned that they also ate the adults. Beetles, termites, mayflies, praying mantises were consumed as adults, whereas dragonflies were consumed exclusively in the aquatic larval stage. Likewise silk moths: they were consumed only when they were still caterpillars, ready to pupate or when they had just turned into a pupa.

The expressed preferences for different stages almost certainly depended on a variety of factors: palatability of the insects (which undoubtedly changes between developmental stages), availability and convenience with which the sought-after insects and their developmental stages can be obtained. Furthermore taboos or religious beliefs may be involved in the decision to avoid certain species and/or developmental stages [11].

\section{Comparisons between ethnic groups with respect to edible insects}

Similarities and differences with regard to the entomophagic practices among the studied tribal groups exist. The total number of species, identified by us to be consumed by members of the Wangcho (Wancho) tribe, is 20. This, being the highest number of insect species used as food among the studied tribes, is followed by the Nocte, Chakma, Sinpho, Deori; the smallest number of insect species used as food, according to our survey, was 9 and associated with the Tangsa. Insect preferences and selectivity can be discussed in the context of species availability, but tribal tradition, culture and religious beliefs must also be considered, assuming that physiological differences of taste receptors between different human beings are negligible.

In the course of our survey it was noticed that of the other tribes in our study area, the Singpho were the most hesitant or shy to express that they habitually ate insects. However, kind persistence and expressing a positive attitude towards the consumption of insects by humans helped to create an environment of trust and made Singpho informants to reveal that they regularly consumed 14. different kinds of insects. Several people of the Singpho tribe expressed and accepted a negative attitude towards eating insects. Singpho tribals consume fewer orthopteran species than members of tribes that are mainly engaged in agricultural activities. Singpho people do not widely practice agriculture themselves, but get it done through other tribals, whom they engage to work in their fields. Those workers collect produce for the Singpho along with some of the Singpho's preferred edible insects from the field. With respect to Orthoptera, Singpho consume only one acridid species and two species of gryllids. Singpho themselves are often engaged in tea plantation/cultivation and use yams and other edible tubers as their staple food.

Members of the Deori tribe practice mostly agriculture. They consume 6 orthopteran species (3 acridids, 1 tettigonid and 2 gryllids), which is the highest number among the studied tribes. Along with their agricultural activity, Deori tribals also practice weaving and culture three varieties of silk moth (Lepidoptera, Saturnidae), whose larvae and pupae (including those of a wild species) they consume. Except for the Deori, members of the other five tribes questioned by us, did not mention the intake of silk worm larvae at all, although a small number of respondents of the Singpho mentioned their inclination towards eating silkworm larvae.

The Tangsa (Mosang or Lumphi) were found not to consume Orthoptera unlike the other tribals mentioned above. If agricultural practices among the tribes influence their acceptance of at least a few orthopteran species, then this assumption does not hold true for the Tangsa, for they also practices shifting cultivation. Probably some other reason prompted them to discard or accept which species of insect they are willing to consume (e.g., they do take species of Hymenoptera and Hemiptera). Tangsa are followers of animistic beliefs, although they have also come under the influence of Theravada Buddhism [13,14] and this might have had some effect on their food insect preferences. This, however, is pure speculation and at the moment cannot be backed up with any evidence.

Members of the Wangcho (Wancho) tribe practice shifting cultivation, but their secondary activities include hunting and fishing for their livelihood. Besides using insects as food, they also use some species, mostly hemipterans, for therapeutic purposes. Out of 7 edible hemipteran species, 4 species were reported to be used only for therapeutic purposes, in particular for treating colds and coughs. A pharmacological assessment of the effectiveness of such treatment remains to be carried out. There are 6 hymenopteran species (occupying different ecological niches) and 3 species of beetle that were reported by our informants to be consumed by them. This demonstrates the dependence of these tribals on the forests and their products small and large, as they are still actively pursuing hunting activities. Four species of Orthoptera, including 2 gryllids and 2 acridids, were also taken as food by the Wangcho (Wancho).

Like the Wangcho (Wancho), the Nocte are also martial Naga tribals, but with their own distinctive life style, beliefs and social norms [15,16]. Remarkably, they mentioned termites, aquatic nymphs of dragonflies (Odonata), and mayflies (Ephemeroptera) as food insect items. The agricultural practice of the Nocte is primarily of the shifting type (jhum), although more and more people have begun to adopt terrace farming as well. In total 16 species, including 4 Orthoptera, 5 Hymenoptera, 3 Hemiptera, 2 Isoptera, 1 Odonata and 1 Ephemeroptera were readily accepted as food by the Nocte. 
The Chakma, ethnically known to be Tibeto-Burman in origin and thus closely affiliated with tribes living at the foothills of the Himalaya, came to the state of Arunachal Pradesh as refugees. Most of them are employed in agriculture on a paid-up basis, usually working for the Singpho tribe in the same district. Our survey revealed that the Chakma consume the highest number of Coleopteran species amongst all of the studied tribes, i.e. 10 species of beetles, out of which 5 are Scarabaeidae, 3 Cerambycidae, 1 belongs to the Lucanidae and 1 to the Buprestidae. The insects are consumed both as grubs and as adults.

The acceptance of this high number of Coleopterans by the Chakma clearly indicates the dependence of these people on the forest's insect inhabitants for their livelihood. Whatsoever of orthopteran species may be present in the field, they also take. Interestingly, our survey amongst the Chakma revealed that in contrast to the other tribes studied by us, no hymenopteran species were taken by them. Whether this is due to a conservation concept specifically aimed at bees, in which the by product of honey is valued more than the insect, or whether it has something to do with the ability of the bees to sting or bite and aggressively defend themselves can currently not be decided.

\section{Conclusion}

What our survey has shown is that between different (and even neighbouring) tribes considerable differences can exist with regard to the numbers and species of insects used as food or used therapeutically. The Wangcho (Wancho) not only consume a wide variety of insects, they also reported the most extensive therapeutic uses of insects. However, in order to obtain reliable and comprehensive information on insect uses in folk medicinal practices, local healers not only need to be identified, they also have to be willing to share their knowledge with the investigator; and that is not always the case. The extensive information provided by the Wangcho (Wancho) with regard to the therapeutic uses of insects, therefore, could be a reflection of a less secretive society or a wider general awareness across the community of the usefulness of insects in health and healing when compared with other tribes. Alternatively, other tribes may simply not find much use for insects in treating sicknesses.

What our results cannot resolve is whether the differences in insect uses (be that for consumption or therapies) between the tribes have arisen out of the need to distinguish themselves from their neighbours or are primarily the consequence of the different environments and climatic conditions, which must affect the composition and abundance of insect species regionally. It is, for instance, obvious that most of the collections of Hemiptera and Hymenoptera take place during the months from November to March, while those of Orthoptera and Coleoptera species occur between May and September.

Agricultural practices between the different tribes can explain some (for example, the agricultural Deori consume mostly Orthopterans, but Singpho who do little work themselves in the fields, consider only one acridid worth eating), but not all differences (the Orthopteraavoiding, agricultural Tangsa stand out as rather exceptional). Additional factors related to myths, taboos, etc. may therefore also contribute to what is deemed acceptable. It is clear, however, that such differences especially in those species taken as a regular food item (irrespective of what the differences are actually based on) lead to a more balanced and economic use of the food insect resource, since the pressure of exploiting this resource is distributed across a larger number of candidates.

\section{Competing interests}

The authors declare that they have no competing interests.

\section{Authors' contributions}

JC carried out the field work and supervised SG's research. SG participated in the field work and in the identification of the insects. VBM- $R$ began the ethno entomological studies in North-East India and participated in the design, coordination, and preparation of the manuscript. All authors read and approved the final manuscript.

\section{Acknowledgements}

The authors are thankful to the University Grants Commission, New Delhi and the Department of Science and Technology New Delhi, for the financial support, through project grants to Dr. J. Chakravorty. Thanks are also due to Rajiv Gandhi University, Arunachal Pradesh, India and Jacobs University Bremen, Germany, for providing facilities to complete this report and to the Robert Bosch Foundation (Germany) for supporting Prof. V.B. Meyer-Rochow 's recent visit to Northeast India. The Zoological Survey of India, Kolkata, helped with the identification for some of the insects.

\section{Author details}

'Biochemical Nutrition Laboratory, Department of Zoology, Rajiv Gandhi University, Arunachal Pradesh 791112, India. ${ }^{2}$ School of Engineering and Science, Jacobs University, Research II (Rm. 37), D-28759 Bremen, Germany. ${ }^{3}$ Department of Biology, Oulu University, Linnanmaa Campus, P.O. Box 3000, FIN-90014 Oulu, Finland.

Received: 24 April 2013 Accepted: 17 July 2013

Published: 19 July 2013

\section{References}

1. Mitsuhashi J: Sekai konchu shoko taizen. Tokyo: Yasaka Shobo; 2008.

2. Meyer-Rochow VB, Chakravorty J: Notes on entomophagy and entomotherapy generally and information on the situation in India in particular. Appl Entomol Zool 2013, 48:105-112. doi:10.1007/s13355-013-0171-9.

3. Meyer-Rochow VB, Changkija S: Uses of insects as human food in Papua New Guinea, Australia, and north-east India: cross-cultural considerations and cautious conclusions. Ecol Food Nutr 1997, 36:159-187.

4. Meyer-Rochow VB: Traditional food insects and spider in several ethnic groups of north east India, Papua New Guinea, Australia and New Zealand. In Ecological implications of minilivestock: Rodents, frogs, snails, and insects for sustainable development. Edited by Paoletti MP. Enfield, USA: Science Publ; 2004:385-409.

5. Chakravorty J, Ghosh S, Meyer-Rochow VB: Practices of entomophagy and entomotherapy by members of the Nyishi and Galo tribes of the state of Arunachal Pradesh (North-East India). J Ethnobiol Ethnomed 2011, 7:5.

6. Ghosh AK, Sengupta T: Handbook on insect collection, preservation and study. Kolkata: Zool Surv India; 1982 
7. Arrow GJ: The fauna of India, including Pakistan, Ceylon, Burma and Malaya: Coleoptera Lamellicornia - Lucanidae and Passalidae. Volume IV. New Delhi, India: Today and Tomorrows Printers and Publishers; 1949:1-274.

8. Atkinman ET: Fauna of Himalaya. Delhi: Cosmos Publications; 1974

9. Vazirani TG: Fauna of Coleoptera, family Gyrinidae and Haliplidae. Kolkata: Zool Surv India; 1984:1-138.

10. Gahan CJ: The fauna of British India, including Ceylon and Burma: Coleoptera (Cerambycidae). Volume 1. New Delhi, India: Today and Tomorrows Printers and Publishers; 1988:1-322.

11. Meyer-Rochow VB: Food taboos: their origins and purposes. J Ethnobiol Ethnmed 2009, 5:18.

12. Neupane FP, Thapa RB, Parajulee MN: Life and seasonal histories of the eri silkworm, Samia Cynthia ricini Hltt. (Lepidoptera: Saturniidae), in Chitwan, Nepal. J Inst Agric Anim Sci 1990, 11:113-120.

13. Baveja JD: New horizons of north east. Nagpur, India: Western Book Depot; 1982:68.

14. Roy S, Rizvi SHM: Tribal customary laws of north east India. New Delhi: BR Publ Corp; 1990:34

15. Das NK: Ethnic identity, ethnicity and social stratification in Northeast India. New Delhi: Inter-India Publ; 1989

16. Fürer-Haimendorf C: Return to the naked Nagas. London: John Murray Publ; 1977.

doi:10.1186/1746-4269-9-50

Cite this article as: Chakravorty et al:: Comparative Survey of Entomophagy and Entomotherapeutic Practices in Six Tribes of Eastern Arunachal Pradesh (India). Journal of Ethnobiology and Ethnomedicine 2013 9:50.

\section{Submit your next manuscript to BioMed Central and take full advantage of:}

- Convenient online submission

- Thorough peer review

- No space constraints or color figure charges

- Immediate publication on acceptance

- Inclusion in PubMed, CAS, Scopus and Google Scholar

- Research which is freely available for redistribution 